\title{
Predictor of Successful DJ Stent Insertion in Advanced Cervical Cancer
}

Kadek Budi Santosa ${ }^{1 *}$, Made Moniaga Prawira ${ }^{2}$, Ida Bagus Putra Pramana ${ }^{1}$, Pande Made Wisnu Tirtayasa ${ }^{1}$, Wayan Yudiana ${ }^{1}$ Gede Wirya Kusuma Duarsa ${ }^{1}$, Anak Agung Gede Oka ${ }^{1}$

${ }^{1}$ Department of Urology, Medical Faculty of Udayana University, Sanglah Hospital, Denpasar, Indonesia; ${ }^{2}$ Medical Doctor, General Practitioner, Medical Faculty of Wijaya Kusuma University, Surabaya, Indonesia

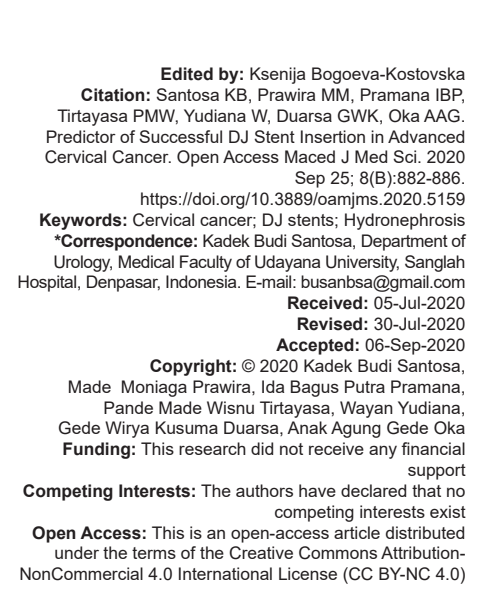

Abstract

BACKGROUND: Metastatic cervical cancer in the ureter may lead to obstructive uropathy due to mechanical ureteral blockage. The insertion of a double $\mathrm{J}$ (DJ) stent is a urinary diversion option that can be offered to the patients, but it becomes challenging due to the high rate of failures.

AIM: The aim of the study was to determine the factors that predict the success of DJ stent insertion in obstructive uropathy due to advanced cervical cancer.

MATERIALS AND METHODS: The patients studied were those with obstructive uropathy due to advanced cervical cancer from 2017 to 2020 in Sanglah General Hospital. The research subjects were divided into two groups: First were the samples of successful DJ stent insertions and the second were those that failed. In the analysis, the Chisquare tests were used for categorical data, while the independent t-tests were used for normally distributed data. Logistic regression analyses which involved both the univariate and multivariate were conducted to determine the factors that aided the success of DJ stent insertions.

RESULTS: Retrograde stent insertion of DJ stents was conducted on 100 patients. Successful insertions were found in 57 patients $(57 \%)$, while those that failed were observed in 43 subjects $(43 \%)$. The results of multivariate regression analyses showed that low-grade hydronephrosis (odd ratios $[\mathrm{OR}]=62.024 ; \mathrm{p}=0.000$; confidence interval $[\mathrm{Cl}]=9.485$ 405.596), normal albumin levels $(\mathrm{OR}=5.856 ; \mathrm{p}=0.018 ; \mathrm{Cl}=1.359-25.243)$, lower Federation of Gynecology and Obstetrics $(F I G O)$ staging $(O R=14.985 ; p=0.007 ; \mathrm{Cl}=2.108-106.536)$, and a history of radiotherapy $(O R=8.758$; $p=0.005 ; \mathrm{Cl}=1.943-39.477$ ) were the significant factors for predicting the success of DJ stent insertions.

CONCLUSION: Low-grade hydronephrosis, normal albumin levels, lower FIGO staging, and a history of radiotherapy are the strong factors for predicting the success of DJ stent insertions in obstructive uropathy due to advanced cervical cancer.

\section{Introduction}

Cervical cancer is one of the most commonly found malignant diseases in women. Approximately 500,000 new cases of cervical cancer are recorded each year and cause about 274,000 deaths per year worldwide. In Sanglah Hospital, there were 574 cases of cancer recorded from 2011 to 2015 . More than $40 \%$ of the cervical cancer patients were already in advance stage and required urine diversion since they have been experiencing obstructive uropathy [1], [2], [3].

Metastatic cervical cancer in the ureter may lead to obstructive uropathy due to mechanical ureteral blockage. The pathological mechanisms in these regards include; encasement and concentric occlusion of the ureter by the metastatic tumor deposits, direct extrinsic pressure, vigorous fibroblastic reaction leading to stricture, and fibrosis formation resulting in obstructive angulation, or the invagination of the upper ureteral segment into the lower portion [4], [5].
Urinary diversion in cases of obstructive uropathy due to advanced cervical cancer is needed to prevent deteriorating kidney function and has been proven to increase the chance of survival [6], [7]. The insertion of a double $\mathrm{J}$ (DJ) stent and the percutaneous nephrostomy is urinary diversion options that can be offered to the patients. Although several studies have consistently discovered that percutaneous nephrostomy is slightly better in restoring kidney function, psychosocially, patients are more receptive to DJ stent insertion since it is generally accepted and may be left in place for long periods of time when necessary, without an external tube [7], [8], [9]. In palliative cases, the patient's preference is respected in accordance with the medical options provided [2], [9]. DJ stent insertions in metastatic ureteral obstruction due to advanced cervical cancer are becoming challenging due to the high rate of failures [10]. Informed consent before a successful DJ stent installation, endoscopic equipment preparation, anesthetic factors, and the possibility of time extension due to insertion failure are the issues to consider. Therefore, this study aims to evaluate the 
factors that predict the success of DJ stents insertion in obstructive uropathy due to advanced cervical cancer.

\section{Materials and Methods}

The subjects observed in this study were those who had obstructive uropathy due to cervical cancer from 2017 to 2020 and performed DJ stent insertion attempt in the Urology Department of Sanglah Hospital. DJ stent insertion was considered to be successful if it inserted properly in at least one side of the kidney. Pre-operative data collected, including the 2D ultrasonography results, which showed the degree of hydronephrosis (classification of the Society of Fetal Ultrasound/SFU), cancer diameter, and the presence of cancer infiltration in the bladder. Laboratory data were collected, including blood urea nitrogen (BUN) levels, creatinine, and blood albumin. Other clinical data comprised the cervical cancer staging, based on the International Federation of Gynecology and Obstetrics (FIGO) classification and also a history of chemotherapy, radiotherapy, and surgery [11], [12]. Furthermore, the research subjects were divided into two groups: The first group is the one that succeeds in inserting the DJ stent, while the second group is those who fail. This study was analyzed using the Chi-square tests for categorical data, while the independent t-tests were used for distributed numerical data. Logistic regression analysis, which involves both the univariate and multivariate were carried out to determine the factors that aided the success of the DJ stents' insertion. The odds ratios (OR) of each characteristic and the confidence interval $(\mathrm{Cl})$ were calculated to find significant differences. Data were analyzed using IBM SPSS software version 26.

\section{Results}

Table 1 summarized the characteristics and results of the univariate analysis that influenced the success of DJ stent insertions. Among the 100 patients, 57 were successful, while 43 were fail. The average age of Group I was $50.35 \pm 8.15$ and Group II was $50.97 \pm$ 10.49. The degree of hydronephrosis of the two groups was evaluated using 2D ultrasonography and classified according to SFU standards. In Group I, the majority of the hydronephrosis were Grades 1 and 2, and in the reverse group, they were Grades 3 and 4 (Figure 1). The diameter of cancer and the bladder infiltration was identified through ultrasonography. In Group I, the mean diameter was determined as $3.34 \pm 1.02 \mathrm{~cm}$, while in Group II it was $6.31 \pm 1.13 \mathrm{~cm}$.
Table 1: Patient characteristics and univariate analysis influenced the success of DJ stent insertion

\begin{tabular}{llll}
\hline Characteristic & Success (Group I) $\mathrm{n}=57$ & Failure (Group II) $\mathrm{n}=43$ & $\mathrm{p}$-value \\
\hline Age & $50.35 \pm 8.15$ & $50.97 \pm 10.49$ & $0.738^{\mathrm{a}}$ \\
Hydronephrosis & & & $0.000^{\mathrm{b}}$ \\
$\quad$ Grade I & $15(26.3 \%)$ & $0(0 \%)$ & \\
Grade II & $25(43.9 \%)$ & $4(9.3 \%)$ & \\
Grade III & $14(24.6 \%)$ & $21(48.8 \%)$ & \\
Grade IV & $3(5.3 \%)$ & $18(41.9 \%)$ & $0.000^{\mathrm{a}}$ \\
Cancer diameter & $3.34 \pm 1.02$ & $6.31 \pm 1.13$ & $0.009^{\mathrm{b}}$ \\
Bladder infiltration & $\mathrm{n}=57$ & $\mathrm{n}=43$ & \\
Yes & $34(59.6 \%)$ & $36(83.7 \%)$ & \\
No & $23(40.4 \%)$ & $7(16.3 \%)$ & $0.000^{\mathrm{a}}$ \\
Laboratory findings & & & $0.001^{\mathrm{a}}$ \\
BUN level & $21.2 \pm 15.42$ & $40.6 \pm 29.06$ & $0.000^{\mathrm{a}}$ \\
Creatinin level & $2.2 \pm 2.4$ & $4.7 \pm 4.4$ & $0.079^{\mathrm{b}}$ \\
Albumin level & $3.7 \pm 0.7$ & $3.1 \pm 0.7$ & \\
Staging (FIGO) & $\mathrm{n}=57$ & $\mathrm{n}=43$ & \\
Stage 3 & $47(82.5 \%)$ & $39(90.7 \%)$ & $0.004^{\mathrm{b}}$ \\
Stage 4 & $10(17.5 \%)$ & $4(9.3 \%)$ & \\
Medication history & & & \\
Operation & $1(1.73 \%)$ & $5(11.4 \%)$ & \\
Chemotherapy & $14(24.3 \%)$ & $12(27.5 \%)$ & \\
Radiotherapy & $36(62.5 \%)$ & $10(22.9 \%)$ & \\
\hline
\end{tabular}

The laboratory results of Groups I and II were compared. The average BUN score for Group I was $21.2 \pm 15.42$, while for Group II, it was $40.6 \pm 29.06$. The creatinine values for Groups I and II were $2.2 \pm 2.4$ and $4.7 \pm 4.4$, respectively. The albumin level for Group I was $3.7 \pm 0.7$, while for Group II, it was $3.1 \pm 0.7$. The clinical stage of cervical cancer was classified according to FIGO, and the ultrasonography was conducted in the Radiology Department of Sanglah Hospital. The dominant clinical stage of the two groups was 3B, with 47 (82.5\%) patients in Group I and 39 (90.7\%) in Group II, followed by Stage 4, in each group were 10 (17.5\%) and $4(9.3 \%)$, respectively.

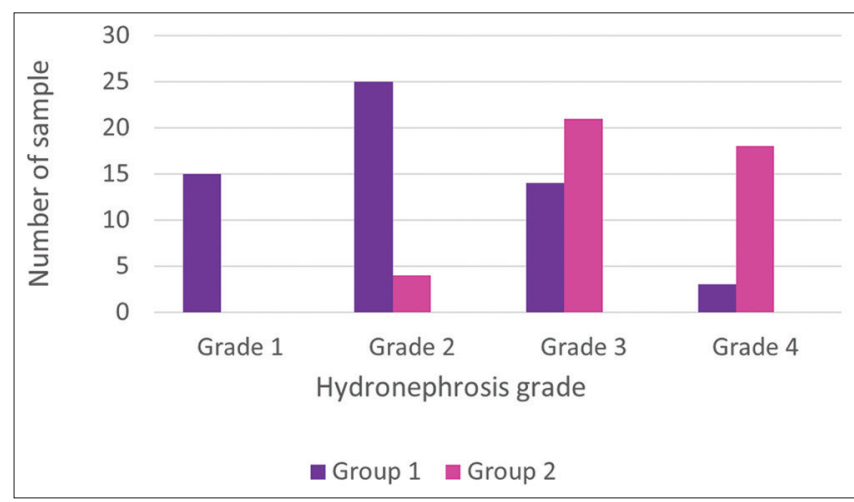

Figure 1: Hydronephrosis grade in each group

Based on previous procedures history, each group was classified according to their treatment record, surgery (total abdominal salpingooophorectomy hysterectomy), chemotherapy, and radiotherapy. Patients who were treated with $\mathrm{TAH}$ BSO were patients who initially had early cervical cancer (stages $\leq 2 \mathrm{~A}$ ) and further experienced recurrent and progression with concomitant obstructive uropathy. At our institution, many patients with advanced cervical cancer have to wait for radiotherapy queues and are given chemotherapy. The combination of carboplatin and paclitaxel is considered less toxic and had similar effectiveness compared to cisplatin and paclitaxel. In Group I, 42 (73\%) patients were found a history of treatment procedures; only $1(1.73 \%)$ performed 
surgery, 14 (24.3\%) received chemotherapy, and 36 $(62.5 \%)$ performed radiotherapy. In Group II, 24 (55\%) patients were found a history of treatment procedures; $5(11.5 \%)$ performed surgery, $12(27.5 \%)$ received chemotherapy, and $10(22.9 \%)$ performed radiotherapy.

The characteristics of the pre-operative patients and the results of the univariate analysis showed that grade hydronephrosis $(p=0.000)$, cavity diameter $(p=0.000)$, bladder infiltration $(p=0.009)$, BUN levels $(p=0.000)$, creatinine $(p=0.001)$, albumin $(p=0.001)$, and history of surgery $(p=0.004)$ aided the success of DJ stent insertions, while the age and staging features were exceptions. The results of multivariate regression analysis of the factors that influenced the success of DJ stent insertions were illustrated in Table 2. Low-grade hydronephrosis $(\mathrm{OR}=62.024 ; \mathrm{p}=0.000 ; \mathrm{Cl}=9.485$ 405.596), albumin levels $(O R=5.856 ; p=0.018$; $\mathrm{Cl}=1.359-25.243), \mathrm{FIGO}$ staging $(\mathrm{OR}=14.985$; $\mathrm{p}=0.007 ; \mathrm{Cl}=2.108-106.536)$, and history of radiotherapy $(\mathrm{OR}=8.758 ; \mathrm{p}=0.005 ; \mathrm{Cl}=1.943-39.477)$ were significant factors for predicting the success of DJ stent insertions (Table 2).

Table 2: Multivariate analysis of factors influenced the success in DJ stent insertion

\begin{tabular}{llll}
\hline Factors & $\mathrm{p}$-value & $\mathrm{OR}$ & $95 \% \mathrm{Cl}$ \\
\hline $\begin{array}{l}\text { USG findings } \\
\quad \text { Lower grade hydronefrosis }\end{array}$ & 0.000 & 62.024 & $9.485-405.596$ \\
$\quad \begin{array}{l}\text { Bladder infiltration } \\
\text { Laboratory findings }\end{array}$ & 0.075 & 3.951 & $0.871-17.935$ \\
$\quad$ BUN level & & & \\
$\quad$ Kreatinin level & 0.233 & 2.291 & $0.586-8.951$ \\
$\quad$ Albumin level & 0.675 & 1.525 & $0.212-10.963$ \\
$\quad$ FIGO staging & 0.018 & 5.865 & $1.359-25.243$ \\
$\quad$ Radiotherapy history & 0.007 & 14.985 & $2.108-106.536$ \\
\hline
\end{tabular}

\section{Discussion}

In this study, $43 \%$ of patients had unsuccessful DJ stent insertions which were caused mostly by the difficulty in locating the ureteric orifice. The second reason was due to the stricture and fibrosis of the distal ureteral and angulation which caused a severe blockage. Several studies reported that the percentage of failure from DJ stent insertions ranged from $16 \%$ to $58 \%$, which was caused by urinary tract obstruction, resulting from cervical malignancies [9], [13]. The high unsuccessful DJ stent insertions were related to advanced-stage cervical cancer, where cellular infiltrations spread to the bladder and ureteral tissues [14]. The metastases of the ureter, which started with the periureteral infiltration by tumor cells, resulted in the compression of the ureteral wall. The transmural, muscular coat, perilymphatic, vascular layers, the mucosal, and submucosal nodules were also affected by the tumor cells [14], [15].

The findings of bladder and ureteral wall involvement by the metastases and hydronephrosis can be detected on radiography using USG. Bladder infiltrations were identified based on the morphological changes in its walls and mass indenting the base of the bladder [16]. The multivariate analysis showed that bladder involvement that was detected on ultrasonography was not a significant factor for predicting the success of DJ stent insertion. These results indicated that mechanical obstruction caused by metastasis cannot be easily assessed from USG. The weakness of this study was the use of conventional 2D ultrasound. Although its accuracy was lower than that of transvaginal 3D, 2D was still used for screening infiltration of the bladder in advanced cervical cancer patients at our institution because it is more practical and cheaper compared to CT scans, MRI, and urine cytology [17]. From the results of multivariate analysis, it was concluded that low hydronephrosis grade was a strong predictor of the success of DJ stent insertion. The result of the OR hydronephrosis value was high, and was 62,024 , according to the study conducted by Wang et al. [9], while those from both the univariate and multivariate analyses were 5.73 and 6.45 , respectively. The grade of hydronephrosis was correlated to the degree of mechanical obstruction at the ureter; therefore, the heavier it is, the more difficult it is to insert the DJ stent.

The laboratory tests showed that BUN and creatinine levels in patients with successful DJ stent insertions were much lower than in those that failed. However, the results of the multivariate analysis indicated that BUN and creatinine levels were not significant predictors. This corresponds with the study conducted by Danilovic et al. [18], that serum preoperative creatinine had no influence in the insertion of DJ stents, but Wenzler et al. [19] stated that DJ stent insertion failure was attributed to male patients with high creatinine levels. Similar to Wenzler, Pedamallu [20] also confirmed the statement. The increased levels of BUN and creatinine were related to the degree of ureteral obstruction due to tumor infiltration, and bilateral ureteral obstruction resulted in decreased blood flow and glomerular filtration rate of both kidneys. This mechanism caused an increase in BUN and creatinine levels while decreasing the $24 \mathrm{~h}$ of urine production. Besides obstruction, there were other factors that caused the increased levels of BUN and creatinine in patients with advanced cervical cancer, which include: Dehydration, sepsis, history of diabetes or renal hypertension, and kidney diseases [21]. The laboratory results also indicated that low albumin levels were strong predictors of unsuccessful DJ stent insertions based on multivariate analysis. This corresponds with the research conducted by $\mathrm{Yu}$ et al. [22] and Yoon et al. [23] that hypoalbuminemia was associated with early failure of ureteral stent function. It was also observed that cancer patients had low serum albumin values, coupled with the presence of malnutrition and inflammation; therefore, those with hypoalbuminemia often have a progressive disease and worse prognosis. Giving albumin before DJ stent insertion will not increase the chance of successful DJ 
stent insertion because the pathology of the ureter has already occurred due to cervical cancer progression.

There were two criteria for diagnosing $3 \mathrm{~B}$ cervical cancer based on the current FIGO classification: Fixed tumor in the bladder wall beside the pelvic bone, or the presence of undefined hydronephrosis due to other factors. For determining Stage 4, it is tumor infiltration on the mucosa of the bladder, rectum, or pelvic bone [12]. The clinical classification based on FIGO criteria was a strong predictor of DJ stent insertion since the lower the cancer stage, the higher the insertion success level. This was also in correspondence with a study conducted by Soetojo [2] that the level of stent insertions in the ipsilateral kidney with hydronephrosis depends on the clinical stage of cervical cancer.

Previous studies conducted by Chung et al. [24] and Chitale et al. [25] did not determine the history of radiotherapy as a predictor. In this study, DJ stents were easily inserted in patients that underwent radiation therapy and correspond with the research conducted by Liu et al. [26], which stated that cervical cancer patients that had been previously radiated had lower disease progression and higher survival rates. The effect shrunk the heavy tumor pressing on the ureter wall, thus used in the early stages of the disease.

\section{Conclusion}

Low-grade hydronephrosis, normal albumin levels, lower FIGO staging, and a history of radiotherapy are the strong factors for predicting the success of DJ stent insertions in obstructive uropathy due to advanced cervical cancer.

\section{References}

1. Darmayasa IM, Made BD, Hari WS. Kualitas Hidup Pasien Kanker Serviks Yang Dirawat di Ruang Cempaka Ginekologi RSUP Sanglah Denpasar. Jakarta: Disampaikan Pada PIT HOGSI X; 2017. https://doi.org/10.15562/medicina.v50i2.822

2. Soetojo S, Nurdin AT. Charateristics of gynecological abnormalities and types of urine diversion at $\mathrm{Dr}$ Soetomo Hospital, Surabaya, Indonesia, in three-year period. Fol Med Indones. 2019;55:134-8. https://doi.org/10.20473/fmi. v55i2.14347

3. Oktaviani BD, Sriwidyani NP, Sumadi IW. Karakteristik klinikopatologi penderita kanker serviks uteri berdasarkan data di laboratorium patologi anatomi RSUP Sanglah Denpasar Tahun 2011-2015. E J Med Udayana. 2018;7(8):1-6. https://doi. org/10.35790/ecl.8.1.2020.27814

4. Cohen WM, Freed SZ, Hasson J. Metastatic cancer to the ureter: A review of the literature and case presentations. J Urol. 1974;112(2):188-9. https://doi.org/10.1016/s0022-5347(17)59679-2 PMid:4843329
5. Arvind NK, Singh O, Gupta S, Ali Q. Ureteral metastasis as the presenting manifestation of pancreatic carcinoma. Rev Urol. 2013;15(3):124-30

PMid:24223025

6. Kouba E, Wallen EM, Pruthi RS. Management of uretera obstruction due to advanced malignancy: Optimizing therapeutic and palliative outcomes. J Urol. 2018;180(2):444-50. https://doi. org/10.1016/j.juro.2008.04.008

PMid: 18550089

7. Tan S, Tao Z, Bian X, Zhao Y, Wang N, Chen X, et al. Ureteral stent placement and percutaneous nephrostomy in the management of hydronephrosis secondary to cervical cancer. Eur J Obstet Gynecol Reprod Biol. 2019;241:99-103. https://doi. org/10.1016/j.ejogrb.2019.08.020

PMid:31484100

8. Ahmad I, Pansota MS, Tariq M, Saleem MS, Tabassum SA, Hussain A. Comparison between Double J (DJ) ureteral stenting and Percutaneous Nephrostomy (PCN) in obstructive uropathy. Park J Med Sci. 2013;29(3):725-9. https://doi.org/10.12669/ pjms.293.3563

PMid:24353616

9. Wang JY, Zhang HL, Zhu Y, Qin XJ, Dai B, Ye DW. Predicting the failure of retrograde ureteral stent insertion for managing malignant ureteral obstruction in outpatients. Oncol Lett. 2016;11(1):879-83. https://doi.org/10.3892/ol.2015.3961 PMid:26870299

10. Noegroho BS, Mustafa A. Predictive factor for successfu retrograde ureteral stent insertion in obstructive uropathy due to advanced cervical cancer. Urogynaecologia. 2019;31(1):221. https://doi.org/10.4081/uij.2019.221

11. Fernbach SK, Maizels M, Conway JJ. Ultrasound grading of hydronephrosis: Introduction to the system used by the society for fetal urology. Pediatr Radiol. 1993;23(6):478-80. https://doi. org/10.1007/bf02012459 PMid:8255658

12. Sobin LH, Wittekind L. International Union Against Cancer (UICC) TNM Classification of Malignant Tumours. $6^{\text {th }}$ ed. Hoboken, NJ: Wiley; 2002. p. 155-7.

13. Chan ES, Matsuda T. Endourology Progress Technique, Technology and Training. Singapore: Springer Nature; 2019.

14. Yamagami T, Ide K, Nishio K. Studies on the pathophysiology of ureteral lesion in treatment for the uterine cervical cancer. Kurume Med J. 1973;20(2):113-8. https://doi.org/10.2739/ kurumemedj.20.113

15. Singh I, Strandhoy JW, Assimos DG. Pathophysiology of urinary tract obstruction. In: Campbell-Walsh Urology. $10^{\text {th }}$ ed. Philadelphia, PA: Elsevier Saunders; 2012. p. 1087-120. https:// doi.org/10.1016/b978-1-4160-6911-9.00040-2

16. Huang WC, Yang JM, Yang YC, Dan Yang SH. Ultrasonographic characteristics and cystoscopic correlates of bladder wall invasion by endophytic cervical cancer. Ultrasound Obstet Gynecol. 2006;27(6):680-6. https://doi.org/10.1002/uog.2775 PMid:16710879

17. Chou CY, Hsu KF, Wang ST, Huang SC, Tzeng CC, Huang KE. Accuracy of three-dimensional ultrasonography in volume estimation of cervical carcinoma. Gynecol Oncol. 1997;66(1):89-93. https://doi.org/10.1006/gyno.1997.4714

18. Danilovic A, Antonopoulos IM, Mesquita JL, Lucon AM Likelihood of retrograde double-J stenting according to ureteral obstructing pathology. Int Braz J Urol. 2005;31(5):431-6. https:// doi.org/10.1590/s1677-55382005000500003

19. Wenzler DL, Kim SP, Rosevear HM, Faerber GJ, Roberts WW WolfJS.Success ofureteralstentsforintrinsicureteralobstruction.J Endourol. 2008;22:295-9. https://doi.org/10.1089/end.2007.0201 PMid:18294036 
20. Pedamallu R, Subramanian S. Factors predicting success rate of retrograde ureteric stenting in managing patients with ureteric obstruction-our experiences in a South Indian tertiary institute. Internet J Urol. 2015;14(1):1-7.

21. Higgins C. Urea and the Clinical Value Measuring Blood Urea Concentration. Available from: http://www.acutecaretesting.org. [Last accessed on 2020 May 23].

22. Yu SH, Ryu JG, Jeong SH, Hwang EC, Jang WS, Hwang IS, et al. Predicting factors for stent failure-free survival in patients with a malignant ureteral obstruction managed with ureteral stents. Korean J Urol. 2013;54(5):316-21. https://doi. org/10.4111/kju.2013.54.5.316

PMid:23700497

23. Yoon $\mathrm{JH}$, Park $\mathrm{S}$, Moon $\mathrm{KH}$, et al. Renal function is associated with prognosis in stent-change therapy for malignant ureteral obstruction. Investig Clin Urol. 2018;59(6):376-82. https://doi. org/10.4111/icu.2018.59.6.376

PMid:30402570
24. Chung SY, Stein RJ, Landsittel D, Davies BJ, Cuellar DC, Hrebinko RL, et al. 15-year experience with the management of extrinsic ureteral obstruction with indwelling ureteral stents. J Urol. 2004;172(2):592-5. https://doi.org/10.1097/01. ju.0000130510.28768.f5

PMid:15247739

25. Chitale SV, Scott-Barrett S, Ho ET, Burgess NA. The management of ureteric obstruction secondary to malignant pelvic disease. Clin Radiol. 2002;57(12):1118-21. https://doi. org/10.1053/crad.2002.1114

PMid:12475538

26. Liu YM, Ni LQ, Wang SS, Lv QL, Chen WJ, Ying SP. Outcome and prognostic factors in cervical cancer patients treated with surgery and concurrent chemoradiotherapy: A retrospective study. World J Surg Oncol. 2018;16:18. https://doi.org/10.1186/ s12957-017-1307-0

PMid:29378625 